\title{
The southern jurist as a teacher of laws: an interview with Upendra Baxi
}

Sundhya Pahuja ${ }^{1}$ and Adil Hasan Khan ${ }^{2}$

\begin{abstract}
This interview was conducted with Upendra Baxi in early October, 2015 as part of the authors' Eminent Jurists Video Archive Project. The interview covers Baxi's formative early years in Rajkot, his education and taking up of a life of a legal scholar, including his basic legal training at the Government Law College in Bombay, graduate education at Berkeley (California), and his early career as a lecturer at the University of Sydney. In a wide ranging discussion, with his usual mixture of intellectual dexterity, endless generosity and good humour, Baxi illuminatingly discusses his understanding of the significant notions of normative expectations, eurocentrism, self-determination, along with the ongoing significance and legacies of B.R. Ambedkar and M.K. Gandhi, the experience of proposing (and eventually teaching) a course on aboriginal peoples' rights in a setter-colony, and the duties and responsibilities that come with inhabiting the roles of being teachers and students of law, amongst other things.
\end{abstract}

\section{Keywords}

Upendra Baxi · Education · Normative expectations · Australia · Aboriginal peoples' rights · Eurocentrism

\section{Day one: New Delhi, October 2, 2015}

Sundhya Pahuja (SP): We were hoping that today you might tell us a little bit about your personal biographical background and to talk a little bit about how you came to study law and those sorts of things. Will you start by telling us a little about your personal background before University?

Upendra Baxi (Upen): Oh well, I don't know what I will say. I was born and studied in a place called Rajkot. It was a Princely State. I was born just when the Second World War had ended, so you can guess, precisely when [laughs mischievously]! I studied for my matriculation there, and I remember my grandfather was a very learned person - a Pleader. I grew up in a joint family house. I had seven Aunts. My father had an elder brother who had died but had three younger brothers. So, it was a huge house! All that I remember about my childhood in that place was the love and affection of my grandmother and also that she lustily participated in the joint family politics and constantly set up one woman against the other [laughs mischievously]. My memory of the childhood in that place called Prem Mandir - the Temple of Love - and it was a temple of love because in turn the sisters and brothers produced their own progeny in large numbers, prolific numbers! So much so that now I have lost count. I don't know my cousins, except for those that I'm friends with today. I'm sure there are lots more than I can remember.

\footnotetext{
${ }^{1}$ Professor and Director, Institute for International Law and the Humanities (IILAH), Melbourne Law School, The University of Melbourne, Parkville, Australia, s.pahuja@unimelb.edu.au.

${ }^{2}$ McKenzie Postdoctoral Fellow, Melbourne Law School, The University of Melbourne, Parkville, Australia, khan.a@unimelb.edu.au.
} 
I have two specific memories of the childhood. One is - our women [family members] were sent out, as it were, to a room where they took cow dung to make cakes, and the cakes had to be put up on the wall. For three days nobody could go to them. Later on, I learned that they were having their period. They were considered 'ritually unclean'. I couldn't understand why couldn't I go to my mother for example, when she had to go, or to my Aunt. It was a no-go area and food was left outside. They had to wash their own clothes and could not be helped by the domestic helper. And the second was that somebody or the other was delivering a child [laughs]. I grew up thinking of pregnancy, and there was a special sweet at that time, which was given to pregnant women, which I still like.

SP: Do you have much memory of colonialism during that time?

Upen: Yes, there are a couple of memories etched on me. It was that of a procession or a march by hundreds of thousands of satyagrahis, as they were called. I was very tiny. We had a forefront in our house, a big house, and there was a little place where one could sit and watch. My brother and I were watching this procession, and suddenly my grandfather came running and said: "Go in! Go in!" We disobeyed him but he didn't see us. But I remember that he said to all these people to lie down. It was a big road. He said this in such a stern and loud voice that the people lay down. I asked: "Why? Why?" Obviously on the other side was the cavalry charge and they were going to lathi charge them. When they [the satyagrahis] lay down, they [the colonial police] could not proceed unless they rode over them. So, they stopped. Then the negotiation began and then Section 144 of the Criminal Procedure Code was apparently imposed. It is a colonial law that made it a crime for more than five persons to congregate [once it had been imposed]. That I can remember.

The second memory I have is of Gandhiji's death. We were all in collective mourning, the entire household, and all the households of Rajkot, [and] everywhere in the country. The fact that he was killed made a big impression on me. Ever since then I have been subconsciously thinking about violence, or the dialectic of violence and non-violence, which is, what we do with it? What we do with the fact of violence and the fact of non-violence - not their effects. But I don't have any memories of the Second World War or of even the Partition. A memory I do have is that we had groups of ethnic Ethiopians [the Siddi Community is an ethnic group settled in various parts of India and Pakistan] settled as far as Rajkot.

SP: How? Why?

Upen: I don't know. They were migrants. People say that I have invented the legend, but it is not a legend but pure truth. The legend is with respect to the porter of a horse-carriage. My mother was heavily pregnant with me and she had to deliver me. My thesis is that I was born on the way to the hospital, in the horse-carriage. This man [helped with my birth] and we used to call him Siddhi Uncle - Siddhi is Abyssinian. A dark man with a beard. A very nice man. I still see him in my mind's eye. He took me to hospital. He used to come and tell me all kinds of stories and some were very scary. But they were not stories from the Arabian Nights. They were stories that his grandmother told him. I don't remember the stories exactly now, but some were scary, and some had a very high moral content.

Then I went to school there. I remember at a young age I had got a "Bonnie Baby Prize" from the municipality [laughter]. But the great thing was that in my high school I was excellent, and I got awards, because in sixth standard I could pronounce and spell the word "CAGE" correctly, in a Gujarati medium school. And I read a lot, in a library called Lang Library. By the age of 
twelve I had read all of Thomas Hardy, who made a great impression on me. Then I read Shakespeare. I read all literature and all the classics in this public library. I was fluent, in my sense, in English. But it was, and remains, self-taught. I don't know what a 'gerund' is. Do you? [laughs].

I remember another story which was designed to be traumatic, but it was not for me at that time but the [school] principal behaved as if it were traumatic. It was my matriculation examination. He said: "Baxi your Grandfather has instituted an award for the best student of the year for the student who has got the highest marks". I got my collar up and looked straight at him, thinking he was going to announce the award. He said: "You do definitely deserve an award but on the other side". I did eleven subjects that year - not nine or eight but all of them - and in Geometry I got six out of a hundred [laughter]. And in Geography, I got twelve out of a hundred. He said: "I wish there was a medal I could give you for securing the lowest marks". Principal Bhatt. My goodness! I remember his name. He was a huge man, with a potbelly and immaculately dressed. So, I said: "I will try better next time!" [laughs]. I was a very naughty student.

SP: Literature was your first love? You studied literature first, before law?

Upen: I was not interested in law. I got interested in law only through Shakespeare's plays, as I read them, and Milton's poems. My first essay, for which I won a prize in college, was on the concept of truth in law and literature. It was based on the famous scene from the Merchant of Venice - 'pound of flesh and not a drop of blood' - basically how the law of evidence works for justice and truth, sometimes. And I made up my story from that, that the technicality of law is not always to be feared, as Lady Portia illustrates. Surprisingly, I got the first prize for that essay. I published the second essay I wrote, which was on the right to leisure. This was published in a local journal, for which I [also] got a prize. There I brought in the idea of rights. Then I went to college. At college I did literature and psychology. And then I moved to Bombay where I did my law at the Government Law College (GLC).

SP: Why did you decide to study law?

Upen: Oh! That is a good question. I was seventeen when I came to Bombay and technically, I was underage for a Masters. I met the Principal of the college where I wanted to pursue an MA in literature. At the same time, I got my first employment opportunity. From no less than a woman called Sumati Morarjee! She was the only [female] shipping tycoon in the world, as [director of the] Scindia Steam Navigation Company. Sumati Behn took me under her wing. She said that you can continue your studies, but you must come and join me and be my personal assistant. Later on, in the two or three years that I served the Scindias, I became an officer. I did the history of Scindias for her. She discovered that I had a talent for writing. I wrote four hundred pages, out of which three hundred were published as a book called The Saga of Scindia [Saga of Scindia: Struggle for Revival of Indian Shipping and Shipbuilding (1919-1969)]. The company is no more, but at that time she was at the height of her career.

Banerjee [was the principal of the English College]. When I went to meet him, he said: "First, you are not properly qualified age-wise but, second, you can't do it part-time. Forget doing literature while you are serving". And Sumati Behn would not leave me. Everybody said that I must take the job. In Bombay, in those days, to get a job, at such a young age, at such a nice company such as Scindias! There was a lot of peer-group pressure [on me]. As a result, I joined GLC. It was so dismal that I dropped it after the first semester. Six months. It just killed the soul as it was taught. We have Section 56 of the Transfer of Property Act and we had four 
teachers, who later became principals of various colleges, who taught all of us [the same thing!]. Four times I had to learn the Doctrine of Partition. Everybody began with partition, as if partition was the soul of the Transfer of Property Act. I said that this is just too much. It is arid, dull, full of details and there is no compelling human interest for me, as literature had. So, I just gave it up.

Sumati Behn was very pleased. She said, "Instead of just focusing on the book, I will take you to different parts of the office and then I will send you to Hamburg and London to become a shipping executive. I will appoint you as an assistant manager after you complete this itinerary". I was on my career escalator.

In the second year I joined law again and this time I decided not to worry about the classes. There were only two professors whose classes I attended. One was Ranganath Rao, who was teaching Private International Law and was very good. I still remember him. Later on, I learnt the art of drinking from him. Much later on. But as a teacher he was not an authority figure, this is why I liked him most. He was like a brother, a fellow traveller. He was anything but imposing in that sense. Another teacher whose classes I attended was Dr. Sethna, who invented the 'Synthetic School of Jurisprudence'. He was my teacher in the LLM. He also wrote several books on criminology which are very well-written. To cut the story short, the second time I never looked back. I went to the library instead of classes and read books. I read all the books that were there in jurisprudence. Some were not there and so I went to the librarian [to ask]: "What happened to these books? I want to read them". He said: "I can't do anything about it. They have been borrowed by our principal". And who was the principal? Dr. B.R. Ambedkar! He had borrowed these books and would not return them on ceasing to be the principal. I never met Ambedkar. Later on, I thought why would he have done this? I have a theory about him. He was a Marxian. Therefore, though he did not believe in property, as per the bourgeois system of property they were his property because he had mixed his labour into them by annotating them [laughter]. So, I invented a justification for him. He did not offer any justification.

So, those books I did not read, but I read the rest of them. One book I remember particularly was by Jennings. Another one was by the old English author, Walter Bagehot. He wrote on people. Actually, I must look at Bagehot now because I am working on an idea called 'demosprudence'.

\section{SP: Was it unusual to be teaching Private International Law in Bombay?}

Upen: We had a cluster of subjects in the Masters called International Law and Jurisprudence. We were taught International Law by a man called Firoze Irani, who was a lawyer but was a very good teacher. We were taught jurisprudence by Sethna and a man called Sathe, S.P. Sathe. Irani concentrated primarily on Private International Law, although he did lecture to us about Public International Law. But at that time, and since then, I have not been sure as to this distinction between public and private, and I have reworked it in my own work. With Sathe I [also] did Roman Law and something called Principles of Legislation.

I ran into an altercation with Sathe. And a very bad one! I was reading the newspaper in one of his classes. And he said: "How dare you Baxi! How dare you read the newspaper!" I said: "Sir, I can tell you which book you are referring to, what is the page number, and perhaps the paragraph number". And he said: "You are being insolent. I am doing no such thing. I am reading my notes". I said: "You have written notes from the book. I can tell you the page 
number because I have read them... To make matters simple, I can tell you what you are going to tell us next week and the week after because I have read the same books". It was very impertinent and Sathe took it as a personal affront. I nearly lost my chance to appear for the exams. He told me to: "Get out!" and so I got out and I told him: "I will never come to your lectures". And I didn't go. [As a result] I had a severe problem of attendance. The long and short of it was that the Head of the Department asked me to apologise and I said: "I won't apologise as it is a matter of principle". I told Professor Irani [Head of Department]: "Look here, you are losing a Gold Medallist!' [Laughter]. I didn't get the Gold Medal, I think, but I got a First Class.

We had a very good system in Bombay at that time, which was that [you had to] answer any four questions, not more than four, but not less than one. So, the students had a choice and I wrote only one answer in Jurisprudence.

SP: What was the question? Do you remember?

Upen: The question was on relativism. I was not satisfied with Western jurisprudence and philosophy I had read on the topic and I wanted to know what was the ancient Indian legal thought on it. So, I generally prepared out of interest, though I didn't know this question would come. I discovered a man called Prashara. Sage Prashara was the first relativist. I could read some Sanskrit then. I read him and I read some other commentaries on him in Sanskrit. And he had a notion of, very much like Thomas Aquinas - but this was the 6th century BC what Aquinas called 'eternal law'. Which you can't change unless you are an eternal being. If you are a contingent being, you can't change eternal law and natural law. Prashara said that the eternal law is dharma, which human beings can construct but can't change. They have to believe in dharma! And he said that there is something called Desha Kala Dharma - dharma that varies between desha, or regions, and kala, times. Time and space. It is dharma that varies and later on in my work I found an instance of that in positive law where a sage Madhavacharya, who flourished in the 6th and 7th AD, says that the Shastras laid down the dharma, we cannot change it.

But there was a practical problem. In the South of India there was a system of cross-cousin marriages and these marriages are considered valid. So Madhavacharya applied Parashara. He said that cross-cousin marriage is against the order of nature, but are valid in the South because it is the custom. His account of custom is of interest to international lawyers. He said custom means sadachaar and shistachaar. Sahachaar means behaviour of the wise - sadh. And shistachaar is the behaviour of your peers. So, there are two sources of custom. And, of course, sadachaar meant Brahmins, because only Brahmins were understood as knowing 'righteous behaviour' at that time and non-Brahmins had 'to be told' what was righteous behaviour [as per this system]. So, it is their custom and practices that you must examine. And if upon such an examination you find that the custom is valid then it is valid no matter what the shastras say, as the shastras themselves contain the principle of contextual interpretation and you must apply what the shastras say is the proper interpretation in a particular context. So that is very old.

I got 80 marks in Jurisprudence for that. And that [essay] wasn't complete because time went by and I could never finish with Parashara in my exam answer. Immediately I came back home, before the results, soon after the exam, and I wrote it all out in longhand and I sent it to Bombay Law Reporter. The Bombay Law Reporter of 1963-64 published the article with the shlokas of Parashara. It was a good paper and it was not revivalist in intention. 
I remember that when we discussed international law in the class - when Bay of Pigs happened - we had no discussion of contemporary international law.

SP: So, what were the things being discussed?

Upen: We were discussing from Oppenheim, which was the classic text. They were all textualist of a kind, a limited kind. But to read Oppenheim was difficult because you had to know English. Anyway, for a campus journal, I did write about the Bay of Pigs. As far as I recall, the substance of what I wrote was that Kennedy [US President] was violating international law by claiming self-defence. He had acted on customary law of selfdetermination - that the UN Charter prohibited. That was my line. It was not very polished, but it was there in substance. And, of course, then the Soviets withdrew and that was a tremendous disappointment, in a sense, to me. While I did not want nuclear weapons anywhere - I don't want them even now! - but what I want and what I get are two different matters.

Returning to the reaction I got from Sathe. I met him later in Chicago, when I went there. We had a pizza and beer party and reunion. And he told me that: "You were quite right in challenging me in the class!" although he didn't appreciate the manner in which I did it. And he said: "Let's be friends. I have learned to teach from a Master". He had learned from Professor Ralph Fuchs, who was a great administrative lawyer [in Chicago Law School] and he was a transformed being since then. Sathe reminded me of this insubordination, as it were, by the telling the Delhi Law Faculty [about it] in his lectures in 1994, when I was the Vice Chancellor [at Delhi University], and I came to hear him and he embarrassed me to no end by recalling that entire incident and I remember it now because of his lecture. I had forgotten [about] it!

In that period of my life, and ever since then, I have become an insurgent thinker, but at that time I believed in insubordination.

Adil Hasan Khan (Adil): It would be interesting to connect this with your views in your essay Teaching as Provocation [1990]. What were your influences when you started teaching? Did you have similar experiences with your own students?

Upen: Oh yes! Once in Australia we had the first Aborigine student. I kept on visiting Sydney after I had quit it formally. It was in 1975, when there was Emergency in India. Julius [Stone] had asked me to handle the LLM class on justice. I asked him: "Where were you at with the [teaching]?" and he said he had been dealing with Aristotle, upon which I said that: "This man has nothing to say about justice." This was because in the Nicomachean Ethics, Aristotle said that slavery was justified. So how can you be an ethical thinker, in any epoch, and justify slavery? It bugged me. I went to the class.

There was this student, who had his feet up on the desk and was facing me. He was eating a sandwich [laughs]. He had the same viewpoint. I said: "Professor Stone asked me to speak about Aristotle. He had this theory of justice." At which point he [the student] interrupted me and told me: "This was a fellow who justified slavery, didn't he?" I said: "Yes, but it is a little bit more complex than that, but basically you are right. I also think so". He said: "Why are you teaching Aristotle to us?" I said: "The answer, if there is any approach to an answer, will require a long time. The class, which has just met, formally ends, and everybody is free to go. But I invite you all to beer in the pub across the street". It was hardly 12 o'clock in the daytime. They all came, and we discussed justice till 7 [in the evening]. With beer we did most of the talking 
and listening. And we did not look back! We used a modern term - I do not know whether it has now become a passing fad - 'deconstruction'. Is deconstruction still prevalent, or gone? [laughter]. It was deconstructing and reconstructing justice. I said [to them] if you want to go more contemporary you should look to Edmond Cahn, who was my favourite thinker and was at NYU and who wrote a book called The Sense of Injustice. It is a great book. He was talking about how people expect justice and get disappointed. "They do not know what justice is." This is how Cahn starts: "But everybody knows what injustice is." Whether it is a disappointment of expectations - whether it is by law, or by politics - whether it is something more than expectations that is violated - a norm - they cannot elaborate on it but they are disappointed with something and this is the core of the sense of injustice.

Adil: You write a lot about what you call 'normative expectations' in later work. Could you give us a bit more sense about that?

Upen: I do. I got into this whole business of expectations through Bentham. I did an 'Introduction' to his great book The Theory of Legislation where he mentions the word expectations and does more. He says that law should always follow expectations. I am currently reading a fantastic book by Antonio Negri, who is my favourite, on Spinoza [Spinoza for Our Time: Politics and Postmodernity (2013)]. He is looking back at his own work called The Savage Anomaly [1991]. He is looking at this book by him on Spinoza now, twenty-five years later. He also uses the word expectations. He says that coincidence between reality and expectations is another name for revolution, according to Spinoza.

Bentham did not distinguish between various types of expectations. There is also another great thinker, sadly progressively neglected - in the Anglo-American world at least - Niklas Luhmann, who had never read Bentham but developed a theory. I, by the dint of living a long life [laughs] have read Bentham, as well as Luhmann. Luhmann had a well worked out theory of expectations. He discusses normative expectations - expectations that thrive on their own ruins and are phoenix like and the more they are disappointed, the more you cling to them. He distinguishes this from existential expectations...

SP: So, what provokes the revolution?

Upen: He doesn't worry about revolution, but I will come back to your very important question. In the case of Luhmann, the second category of expectations is that of existential expectations, which do not survive disappointment - contingent expectations. You disappoint them and they vanish. The difference between normative and existential expectations according to him is that normative expectations survive the experience of disappointment, whatever they may be, and there may be wrong and right normative expectations. But the difference between one and the other is the capacity to survive existential disappointment.

In between them there was another great sociologist who is again forgotten - Talcott Parsons. He wrote a magnificent book in the early Cold War period on the structure of social action and he talked about a variable called 'pattern maintenance'. By pattern maintenance he meant something like expectations and law as an integrative mechanism which was integrative because it maintained the level of expectations.

And the fourth influence on me was Julius Stone, who never worried about the theory of expectations and was more Dicean than Weberian. In one chapter where he was criticizing Roscoe Pound, he wrote this about Pound and Dicey: 'In developing countries it the legislature 
which creates expectations. People don't create expectations.' So, the laws come before people ask for them, and law can be looked at as programmed expectation or a pattern maintenance, as Parsons put it. So, for me, and here I return to the question of revolution, there can be revolutionary expectations. Lenin created one. Marx created one. But we need more work on the relationship between expectation and law. We don't have it. We need to read more of Luhmann. He is the only modern life science evolutionist thinker on law. He needs to be appreciated more than he is. But that is my Luhmann worship. I have done my obeisance. Now I can proceed [laughter].

Adil: I would like to ask you if you would connect your own dispositions towards revolutions and utopias with your formation and influence by tragedy - your tragic sensibility as you have put it? And if so, how?

Upen: Oh! Foucault has the very interesting notion of heterotopia. We can roughly say that there are many utopias. There is not one, singular, the Utopia! But there are utopias. Nozick had one, and he wrote Anarchy, Law and Utopia. His utopia is distinctly neoliberal. He just believes in right to property and right of transactions, human rights as side-effects, not deontological - not [important] in themselves but for doing business they can appear as 'sideeffects'.

Everybody has imagination. That is another faculty which after early enlightenment does not appear in our thought, our thinking practices. What is imagination? What is the source of it? Is it a faculty, like reason or empathy? You look around and you rarely find something on imagination.

I don't like the idea of the Utopia because it fetters the imagination at the very beginning of it. So, I am anti-utopian in that sense - consistently so in my writing. But I am also a believer in the freedom to imagine different futures or different worlds, if you like. I say if you are thinking of imagination that is where expectation comes in. Expectations of a revolutionary change. Structural transformation. Everybody refers to a Marxist utopia versus a free-market utopia, versus now, an ISIS Utopia - a terror Utopia. We need a theoretical approach to imagination and then we could speak about a utopic imagination - not utopias as a place - but utopic elements in thought. In that sense, I have contradicted myself as I have several utopic elements in my thought and everybody has, and I am not unique. I don't believe that the search for alternatives is over. And if the search for alternatives is not over then utopic imagination is at work or different expectations are at work. When Derrida speaks of democracy to come, justice to come, everything to come, he is exercising his utopic imagination. Imagination is very central. It is the capacity to imagine, translate, produce ' $\mathrm{X}$ ' number of things. That is why the World Social Forum motto is what I like - 'Other Worlds Are Possible'. The idea of utopic is summed up very well there.

I looked at a lot of 12th and 13th century Arab metaphysics - even though I don't know Arabic. We only know of the figh, we don't know of sharia, and a very few people know of the kalam. If we look at the kalam, the metaphysics of Islam, in the 12th and 13th century, there was a tremendous upsurge of utopic imagination among the Arabs and they have written fantastic works on utopias, rivalling [Thomas] More's later work called Utopia. I read some of them in their English translations. So, there is always this element of utopic imagination at work.

Adil: So, continuing with this question of utopic imagination, I wanted to take you back to your experiences of the Indian independence and decolonization. What was the impact of thinkers 
like Ambedkar and Gandhi on you and of people writing about possible Indias that could be imagined at that time?

Upen: Well, we did a lot of Gandhi. In fact, I can take pride in the fact that his, I think posthumous collection The Law and the Lawyers, is now prescribed all over India. I discovered it a long time ago in the 1970s and [used it] in my unpublished manuscript on the legal profession in India. And one chapter in there raises the problem regarding why the legal profession was claimed to be as being at the forefront of the freedom fight, as against other learned professions. I wanted to know why do the lawyers make this hegemonic claim? And that is when I discovered this book of essays by Gandhi in Gujarati, and which has also been translated into English. And it turns out that the entire Bar once went on strike against Mohandas.

Personally, I don't call him Gandhi as there are too many Gandhis around, politically. And then I don't call him Karamchand because there used to be this espionage serial on television by that name. So, I call him Mohandas.

Well, in a small article in the journal Harijan, Mohandas compared lawyers with cobblers Mochi. For lawyers, cobbler need not be a word of abuse unless you are casteist. [Casteist] Hindus who believed in their own Hinduism were cut to the quick, including the learned profession, and they organised a boycott against Mohandas, which lasted for nine days. In that chapter, I raised the issue as to how can lawyers be at the forefront of the freedom struggle if they went on strike against Mohandas? It doesn't make sense. This was the Bombay High Court Bar which went on this long strike. And Mohandas had to indirectly apologise to the Bar in the Harijan, that he didn't mean [cobbler] in that sense. What was that sense? A cobbler is a cobbler. But the idea here was that a cobbler is a 'low caste person' and you won't compare us with a 'low caste person' as a profession. So, I wrote long chapter in that book on that. At that time, I had not looked at [Roland] Barthes. Later on, I read his Mythologies, and one of the statements which made a great impact on me, that he makes there is: "A myth is a political language". It is in that sense that we say that lawyers were at the forefront of the freedom struggle. No one is going to check. Historians don't have time for the legal profession. Traditional historians have time for dynasties and how they rose and fall. And Subalterns [historians] have no use for 'Dalits'.

The freedom struggle in the sense that it envisaged a casteless constitution was then a utopia, and an anarchist utopia, a subversive utopia. The very imagination was being altered as being anti-Hindu, or anti-majority. Right? So, this is another aspect of utopic imagination - its labelling as anarchic in the time when it occurs. I now don't make a difference between utopic and the anarchic, or anarchical or insurgent. You have to concentrate and decompose or deconstruct the term utopic into several related terms. Normally sociologists begin with the question: how does order arise in society? Anarchists believe in asking the question: why is order necessary at all? There is a complete difference and that is utopic too. Very few people study anarchism as a philosophy and Mohandas practiced it. I have seen very many studies of Mohandas but none of them refer to this fact or enlarge the fact that he believed in his own, in his words 'still small voice'. What was that 'still small voice'? That was conscience. And what is conscience if not anarchic? You can't have a conscience and take somebody else as defining your morality. It is what you invent as morality approves of, and that is where Kant was right.

Ambedkar is a different matter altogether. Ambedkar believed in order but did not believe in one order. Gandhi did not believe in a ritual one order but believed in order. All of Gandhi's 
thought and Satyagraha was switched on and switched off on the capacity of the masses to be non-violent. The moment they turned violent he switched it off or he himself fasted onto death, at which point they switched it off. So, he had a moral switch. There are interesting similarities between Gandhi and Ambedkar.

Ambedkar's utopias consisted in, as he himself espoused it in his own words, 'annihilation of caste'. But Ambedkar believed in order, otherwise he could not have drafted the Constitution. [Ambedkar's Constitution] is a completely casteless constitution as far as his drafting is concerned. He made no compromises. He spoke of other backward classes, and not caste, consistently, if you look at the Constitution. You go through the Constitution and you find that Ambedkar envisioned a casteless society and a secular India. He never envisaged the political reservations to last for more than ten years. Legislative reservations are renewed every ten years by constitutional amendment. In jobs and education, he envisaged reservation for three categories - Scheduled Castes, Scheduled Tribes and Other Backward Classes (income based).

So, Ambedkar the constitution-maker, presented - what I called very early on in 1967 in an article called "Little Done, Vast Undone" in the Journal of the Indian Law Institute (a review article on [Granville] Austin's first book) - a complete assault against caste-society. Austin wrote about the Constitution being the cornerstone of India in which he stressed accommodation and I stressed theorising it as conflict. There is no accommodation in Ambedkar. It is amazing. I was [once] talking to a class in Toronto [about this] and a Canadian student, first year, first semester in Toronto, got very excited. This was in the 1980s. These are students who keep thinking! He had not even heard about India, did not know what Indians looked like, let alone the Indian Constitution. It was my success that I instilled interest in him. He said: "What a tragedy. Why didn't your constitution-makers think about a different strategy than putting this in the constitution? Because this thing can't be solved by putting it in the constitution or the law. You have to have a movement". And I said: "By God!" I mean I had thought about it before but never so bluntly, with such force. I went up to him and I said, "I thank you very much, you have got me thinking". And thereafter my thinking has undergone stress and ambivalence. I still think it is a marvellous achievement, but I don't think it is anywhere near enough. It is a contradiction. There is a normative expectation that their situation will change, and they are daily disappointed if you are untouchable. So, they are repressed, and they will stay repressed, no matter what you put in the Constitution.

Ambedkar's first civil disobedience movement, the Maha Satyagraha in 1937, is very interesting. Mohandas' first satyagraha was for temple entry, while Ambedkar's was about water. The village well from which you could not draw water if you were 'untouchable'. You had to go a long way to get water to drink. Thus, Ambedkar's first Satyagraha was about basic needs while Gandhi's was about basic rights. He [Ambedkar] developed what is now called biopolitics. So, in a sense he programmed expectations of change. He exercised a utopic imagination in the Constitution. And this is a right that no one can take away from you. Gramsci wrote his Prison Notebooks on toilet paper in the prison. You can't do political or legal theory without Gramsci today. That is the power of imagination.

\section{Day two: New Delhi, October 3, 2015}

SP: Will you tell us when did you go to Australia and where did you go and what took you there? 
Upen: I went there from Berkeley and Julius Stone invited me. There is a background to it. As a student doing LLM in Bombay I fancied that I disagreed with Professor Roscoe Pound. I wrote in long hand a letter to Roscoe Pound where I said I disagreed with him for the following points. And among them was the point that Julius Stone later made of the legislature creating expectations/demands. I said why should jurisprudence only be about judicial lawmaking? What about legislative lawmaking? And Pound responded with a nice letter. He was very kind to me, and he said come to Harvard. We Indians have this thing about Guru figures. Pound was a Guru figure. At that time there were invitations from [American] Universities, who wanted Indian students. Cold War and all that. I had invitations from Yale, Berkeley and Harvard.

Roscoe Pound died in the meantime. My theory is that he didn't die because of ripe old age. He died because of India. He came to deliver the Tagore Law Lecture, which became The Ideal Element of Law. Each lecture was for one hour and he had to give seven lectures. The legend is that in the first lecture, after twenty minutes he asked whether there were any questions. There were no questions from the audience. Ultimately somebody at the far end raised a hand and gingerly said: "Sir, we are a poor country. We have paid a first-class fare to you and Mrs. Pound and you are supposed to deliver seven lectures. You have delivered not even one half of the first lecture and you are asking us to participate?" [laughter]. My theory of Pound's death is that he died of "culture shock". He went back to Harvard, but he could not recover from India. This is our contribution to the 'Langdellian Method'.

I [eventually] went to Berkeley and I had this fascination for Kelsen, whom I had read in Bombay. But Kelsen never appeared in the Law School. I loitered around and it turned out that he was the Chairperson of Political Science. He was never a law professor in Berkeley. So, I wanted to study with him. I asked the librarian, because he [Kelsen] was a great reader of books, and he said, "I will take you to the sixth floor of the Berkeley library, which has only Canon law, but you should not disturb Professor Kelsen. He comes there sometimes". And he showed me a figure who was reading a book on a stack but standing on a stool. A short man. He was Kelsen. I waited for him to come down and he came down and passed by me. I said: "Professor Kelsen, I am so and so". He said: "So what?" I felt very dampened. I said: "I have come all the way from India". He said: "I have no time. I don't take any students". He just left. I found him to be very curt and very German. To cut a long story short, like the "wily Indians" that we are [laughs mischievously], I rang up Mrs. Kelsen. She said: "I can't interfere with my husband's activities, but I can tell you when he is in a good mood. On Saturday you should come, and I will give you tea. He is gardening and that is a good time to see him". And that is how I saw Kelsen and we never looked back. All the three years that I was there, I went there every fifteen days.

Kelsen told me praises about Julius Stone. Because Julius Stone had gone and seen him for the first time. I was in Berkeley, but Julius Stone had not seen me on that occasion. He did not have time and he was visiting Kelsen. After which Kelsen got a copy of the Modern Law Review, which contained Stone's article, Mystery and Mystique of the Basic Norm [1963]. And Kelsen said: "Stone literally worshipped at my feet. And complimented me so well. And then, he writes this article criticising my basic norm. How does a man do that?" And I metaphorically held his hand. I didn't want to interfere between two giants. I was a student. Oddly enough he sent his response to Stone to the California Law Review and they, like all American law reviews, are edited by students. And he showed me a letter on one of my visits to him. A twoline letter from the California Law Review rejecting Kelsen's article. Saying further: "We are not a shopping-bag of grievances". Ultimately the article was published in the Stanford Law 
Review [Professor Stone and the Pure Theory of Law (co-authored with Albert A. Ehrenzweig, 1965)].

There was an Australian called John Fleming, who taught Torts there. He was a very lovely man. And I took all LLB courses. John also knew Julius. So, John and Kelsen, I suspect, talked about me to Julius Stone. So, Julius Stone invited me to Sydney Law School for six months, on my way back [to India]. I went there. At that time, we were in the old Phillip Street Building.

SP: What year was that?

Upen: 1967. Opposite that building was a hotel which is not there anymore. It was very dark and dingy, but they had booked it. And that's how I met Julius Stone on Monday morning and Zina Sachs, who was his secretary. And I was given a very large room because there were only large rooms in that place.

And a young Tony Blackshield had just been appointed lecturer in that place. I met several people who I knew by name and respected. Pieter Drost, who wrote two volumes on ethnocide [Humanicide: The Crime of State, Vol. I; Genocide: United Nations Legislation on International Criminal Law, Vol. II (1959)], who was a Dutch man and was a Socialist International organizer. Charles Alexandrowicz from Madras and Krakow. Charles was there [too].

I cannot I tell you for what reasons he [Julius Stone] invited me. But he did and asked me if I would come. He had finished his books, so he did not need any 'epistemic slaves'. I don't think he needed them anyway.

SP: So, what did you do once you got there?

Upen: First of all, I got myself a place to stay because I couldn't stay at the hotel. I stayed in Neutral Bay and I found an uphill street on which to stay because after San Francisco, Berkeley, I was missing the hills! Thrupp Street is where I stayed. 18 Thrupp Street. It was very hilly. I could go [to University] via boat. The apartment was very tiny. It was straight out of Dickens. I couldn't resist that name Thrupp - somewhere, I think in Great Expectations, or some other novel, he has used it.

SP: So, did you go there in order to teach?

Upen: I went there as a Research Fellow, but I did some teaching. When Professor Stone was away, he asked me to teach jurisprudence. And I said, I had never taught. I [was] just a student. He said you know jurisprudence. These are my books. You have read The Province of Law [The Province and Function of Law: Law as Logic, Justice and Social Control (1946)]; you have read Pound. There comes a time when you must teach. At that time there were these huge lecture halls in the library, and I went there at four o'clock. My first lecture was on Maine and then Savigny on historical jurisprudence. And I had done my notes but wasn't prepared for so many students and so many adult students because in those days at 4 o'clock those who were practicing could also come and it also included the LLM classes. So, it was packed indeed. And I would have looked like the frail young man, that I was. Speaking 'Indian English'. Peter Sellers' accent, I called it [laughs]. At that time Peter Sellers was very much the in thing. So, I said: "I speak 'Peter Sellers' English". But I found it difficult... I didn't succeed. I told the class: "I am new. This is my first teaching assignment. And I am sure I am going to make a 
complete nonsense of it. Please bear with me". Basically, it was narration, but I was very much on the edge. It improved with Savigny. But I asked for an additional hour, if they could come on a particular day when they were free, and, lo and behold, they said: "Yes!". And I took it, right or wrong, as a compliment to my teaching.

I tried to go into extra details in my courses. Even during my first teaching of Savigny I went to Papua New Guinea because that is what the Sydney Morning Herald contained regarding their struggle for independence. He [Savigny] was a historical jurist, writing about Germany, how Germany achieved freedom. So, I said [to the students]: "Please bring in the Sydney Morning Herald. Let us learn a little about Papua New Guinea. Who are these people and what is the Australian view? And we will discuss Savigny through that." New Guinea was only new to me at that time. But I read the newspapers, so I said this is something bearing on historical jurisprudence. Or it is a break from it and is a new historical jurisprudence. And I must say from the second class I got a bouquet of comments and questions. I had told them: "Please interrupt me. I will go quiet and that is your time to talk because I can't talk for forty-five minutes". Nowadays it is different. I didn't have to stop, and they raised their hands and participated. And I gave feedback to Julius. And he said "What do you mean? How can they make comments and ask questions? I don't encourage that. I say what I have to say because forty-five minutes is not enough for what I have to say". So, I said: "I am sorry. I experimented". But that was a little teaching experience.

But then I came back from Sydney to Delhi and then back to Sydney in 1969, after a stint as joint editor of the journal here, in the Indian Law Institute ... Staying with Stone, this is how I got some teaching experience, but I couldn't obviously give my best because there was a prestructured course and I was acutely aware that I was doing it as a locum, as a guest lecturer.

I came back because I was very unhappy with Julius Stone. In 1967, when I was there, I literally packed my bags [and left]. There was a man called Sir Percy Spender. He was in the World Court as the Australian judge [on it]. He was a great jurist. And he wrote a dissenting opinion in the South West Africa Case [1966] upholding virtually, what seemed to me, colonialism. At that time things moved very slowly because we didn't have internet. The judgment of the Hague did not arrive for a certain period of time by sea-mail ... Julius Stone wrote three articles in the Sydney Morning Herald in October 1967. And he essentially defended Sir Percy. I was very hot under the collar. I read the whole judgment. I got it [the copy] from the National Library at Canberra, which was a very good library collection. There was nothing you could not find in the National Library of Canberra. So, I read the judgment and I got so angry that anybody could defend colonialism in an era of self-determination and justify the unjustifiable.

At Berkley I did a course on Western Symphonic Music because I like it very much and I wanted to play the piano. Because of my fingers, I was told were very good to play the piano. This digression is necessary. I typed a forty to fifty-page article and I used what Charles Debussy, the music composer, had said about one of Wagner's compositions - that it is difficult when you hear Wagner to make out whether the notes are notes of sunset or a new dawn. That stuck in my memory. So, my [article's] title was 'South West Africa Cases and Julius Stone: A Sunset or a Dawn?'. Something possessed me and I really wrote a tremendous critique of Julius Stone, and of colonialism and of Sir Percy and I tried to show that you can't defend the indefensible. I showed it to Tony Blackshield, who was very close to Stone. He was not an international lawyer, but he was a polymath. He said: "Why do you write all of this?" I said: "Why? I feel very strongly about this and I work with this man and this is no ordinary man, this is Julius Stone!" I disregarded all advice and gave one original copy of the manuscript to 
Zina Sachs to give to Professor Stone. I was a very angry young man [humorously]. For a week we crossed each other like ships on a starry night. We didn't greet each other but were very civil [to each other]. We didn't have any sherry or cigar or anything together. And after a week Julius called me, and he was very red in his face, and he said: "Son, why this venom? I can understand disagreement, but why this diatribe?" And I said: "I feel absolutely laid to waste by Sir Percy Spender, and by your defence of Sir Percy". He said: "You are young, and you must remember something called the diplomacy of scholarly communication". It is a very nice phrase and I have used it [since then]. I said: "Yes. Diplomacy is right. But this is not about diplomacy. It is about self-determination. Do you understand what the historical implications of what you wrote are?" To which he said: "I did not justify colonialism". He made his rational defence, but I think that he was essentially weak on self-determination, and its logic, and its justification. The counter, the anti-colonial struggle, the Nehru Doctrine, the Panchshilla, the Bandung Declaration, all was based on the principle of the right and rationale of selfdetermination. And President Wilson did not discover that principle. Lenin did! In formulating the Constitution of the Soviet Union in 1919. The Soviet's had five Constitutions, and each of [them] preserved the right of federated territory to secede. There is no [other] Constitution in the world which gives the federating unit a right to secede. And normatively, at least, it was there (in the Soviet Constitutions]. We know what Stalin did with it ... but that is an empirical matter. But normatively [it was recognised].

I told Julius: "I think I need to go back. I think we differ here, at a very fundamental juncture". And he said: "Where will you go back? You have no job. You have not completed your SJD". As it happened, quite coincidentally, in that month itself, G.S. Sharma, a professor of jurisprudence and a doyen of Indian teachers, as the Director of the Indian Law Institute, invited me to a joint professorship and associate editorship of the Journal of the Indian Law Institute, and I jumped on it. I told Julius that I was leaving but that this disagreement would remain because the UN Charter must be taken seriously. Julius had a very nice quip about the Charter, from when we were friendly. He said: "Some people don't know English, Son, and they refer to this as Chatter" [laughs]. Come to think of it, this is true. A lot of it is idle chatter or is made into idle chatter by the 'Coalition of the Willing' in Iraq and Afghanistan. That was not what Article 51 of the Charter was meant to mean.

So, Julius let me go and he was very affectionate after that, but he never understood and never received a hostile reaction like this. He worked in the West primarily. He did not work in the Third World. He was interested [in it] as a scholar. He could not take self-determination as value for another reason which I discovered when I came back a second time [to Sydney] - as lecturer and senior lecturer of Jurisprudence and International Law - when Stone recalled me. I came [back] because I had my own difficulties with the [Indian Law] Institute. It was Israel. Stone had strong feelings about the state of Israel. In a Zionist worldview you cannot take selfdetermination seriously, that I worked out later. Because then you have to worry about Palestinian people and what the UN does with regard to the self-determination of Palestinian people. My second difference with him was exactly on this Palestinian issue but that was when I came back to India from Sydney.

SP: Can you go back to the question of indigenous peoples?

Upen: I went to Sydney in 1969 again and was given lectureship. At the end of 1969, some students came to me and Tony Blackshield, and said that they wanted to understand more about [law and] aborigines. I became a very popular teacher in the first year, so they came to me. 
Upen: In the Masters, I taught senior students, international law. And I also taught jurisprudence. I focused on the question of self-determination at the time, especially with regard to Papua New Guinea. [When these students approached us] Tony was very busy at the time. These were very good students. They said we want a course on the aborigines.

\section{SP: Do you remember who any of them were?}

Upen: Oh yes! I meet them every time I go to Australia. It is an event! This old group and some new ones want to meet me. And they come from all parts of Australia with their families. This time [his last visit to Australia] I met some of them I remember. I didn't meet Jim Spigelman on this visit. Jim was at that time private secretary to Gough Whitlam [former PM of Australia]. ${ }^{3}$ And there was also Susan Armstrong, Michael Cooper and others. Michael Kirby, though he was doing his LLM at that time, joined later on.

I did not know anything about the aborigines. So, I ordered, from a very nice bookshop near the end of Phillip Street, three books by Rowley, a Canberra historian, on aboriginal history [C.D. Rowley, The Destruction of Aboriginal Society; Outcasts in White Australia; and The Remote Aborigines]. I read many more. I met an anthropologist in Canberra, who acquainted me with some more literature. There was a woman called Beth Dean who wrote an enormous amount in newspapers, who was an art critic, and she had studied some aboriginal groups' art. I used to cast my net wide though not wide enough because people were not really interested. Only a ghetto of people were interested in aboriginal peoples at that time. I said to my students that you read these books and we will think about it. Ultimately, I decided to do a course on 'Law and Aborigines'. Julius said: "We don't know enough, how can we do a course?" Epistemic problems. But he gave me intellectual autonomy and that is a great blessing. I prepared a course and I gave it to Tony, who looked at it. He did not know much about aborigines either. And I gave it to Jim, and Sue, and Denis, and Michael, and other people to look at. They said it was very good. What we decided was to make it an optional fourth and fifth-year course, and to make it essay based, which was an innovation for that era when everything was exam based. There were to be only twelve students initially, no more.

There was a big storm in the faculty. Dean Shatwell, who was a very good contracts teacher and had written a number of good articles on the Roman Law of contracts, said: "How can you have such a course?" The general outrage was the proposal [of such a class] and not at the content. But epistemologically they put [forward] the same objection, that you can't have such a course. [At the faculty meeting] they immediately kicked the students out, stating that only we teachers could speak in the faculty meeting, and lecturers could only speak after the professors. This was an unwritten rule. There were several unwritten rules. I was not privy to them, so it didn't matter, and I raised my hand. And we had five or six faculty meetings to discuss this. In between I secured a break, with a man called Garth Nettheim, who supported Tony and me in the faculty, and he later became a professor ... And there were a couple of others. Gradually the dissenting voice was not limited to Tony and myself. I had a nickname

\footnotetext{
${ }^{3}$ Spigelman, who later served as Chief Justice of New South Wales Supreme Court, had joined the famous Freedom Ride in February 1965 while an arts student and had captured most of the action on his video camera. The Freedom Ride was composed primarily of University of Sydney students, led by Charles Perkins, one of the first indigenous student to graduate from tertiary education in Australia. The ride journeyed through western New South Wales and sought to draw attention to the injustices faced by indigenous peoples in Australia at the time.
} 
[amongst those opposing the course] at that time which I still remember - BB ['Black Bastard'].

We made our first compromise. I think it was either Tony's or Garth's idea that we call it "Law and Social Justice". I opposed that, but ultimately, I yielded. So, that's what the course came to be called. But the syllabus remained the same. It concentrated mostly on aborigines, but we brought in poverty and legal-aid which were the emerging 'in-things' for Australian legal culture at the time. But out of, let us say, twenty classes, one third was reserved for legal aid, and the rest for Aborigines. So, the focus did not shift. But we had to make a compromise. The course started in 1971, I think. I don't know whether it still persists. This course was then picked up by a woman called Elizabeth Eggleston, who died young [in 1976], in Monash University, and she called it 'Law and Aborigines', and she had much less difficulty. She had contacted us very often ... So, Sydney and Monash were the kind of pioneers in the 1970s of that course.

[In the course] our emphasis was on rights and justice. And out of this course, in the first year itself, arose what would become Millirrpum v NABALCO Pty Ltd [the Gove land rights case, 1971]. The Australian legal system did not recognize and does not recognize social action litigation. Here [in India] our students can file a petition in the highest court of the land and appear before them in person as petitioners. I call it Social Action Litigation, as against the American [terminology of] Public Interest litigation. I will die calling it SAL and not PIL, and I will die a happy person!

SP: What was the relationship of this case with the course?

Upen: I picked up NABALCO [the Millirrpum case] from the newspapers about bauxite mining in the Gove Island in the Northern Territory. The Gove Islanders did not approach us, nor did I go to Gove Island, but we thought that there was a making of a legal challenge. Now the legal challenge was extremely complicated because we had to prove that the Aborigines had a legal system that the common law ought to recognize. So, we worked really hard, my students and I. And evidence was the other main problem. Where do we get the evidence? Where do we get the people to testify? But we could not appear [before the court]. Nor could we file this case in our name, in Australia. So, it was done through a firm of solicitors whose name I forget at the moment [Purcell \& Purcell]. They said you do all this work and we will cross the T's and dot the I's, which is not our way. And we said that we can't pay you. And while misguided, we will try to help you. And they said that was perfectly alright. I love to be misguided. I just love it! So, it was fun. We prepared.

There was a thing, that is still there, called AUSTLA - Australian Universities Law Schools Association - in whose meeting I dissected Justice Blackburn's judgment [in a paper titled 'The Lost Dreamtime, Now Forever Lost: A Critique of the Gove Land Rights Judgment'] in the Millirrpum case. We took the myth of dreamtime. It is a universal aboriginal myth but peculiar also to Gove Island. And what is "dreamtime"? It is an untranslatable notion. So far as you could translate it, you could say roughly that your ancestors visit that place and therefore it is sacred. Now if you emphasize the word sacred it cannot be solely market driven. And you lose your claim before the court that they had "law". Because the definition of bourgeois law is property law and contract law. Freedom to contract, transactions, and associations companies. And this is exactly where we failed. But Mabo [Mabo and others $v$ Queensland (No. 2), 1992] would not have happened but for Justice Blackburn. I do not know how Australian scholars view it now. 
Blackburn recognized that Australian aborigines had a common law recognizable legal system. The first victory of sorts. Secondly, he recognized the usufructuary rights in law. That there was an [indigenous] system of property - he recognized that as an Australian judge. But he said that if you insist on dreamtime then they [the indigenous owners] cannot alienate the property in the market. Therefore, they do not have "property rights" - they have a legal system without property rights. In my view he invented a notion of "a non-bourgeois legal system". So, I wrote for the AUSTLA [conference] a paper which is as yet an unpublished paper. It is an analysis of Blackburn's judgment and a lament. Twenty years later Mabo happens, and it is a great victory. Soon after, there was the Delgamuukw decision [1997] in Canada. I was slightly involved in Delgamuukw. I advised the young lawyers in the Native Title Group in Toronto. They gave me a lot of material. I went especially for this to Toronto. I talked about the Millirrpum struggles ... Millirrpum broke the conspiracy of silence in Australia. Without the Millirrpum case there would be no Mabo, no Native Title etc.

SP: So, after that experience in Australia, how did that influence you when you came back to India?

Upen: I came back to India because this question was asked by my students: "What happens to your Aborigines?" And I did not know, and I said that. I said that I would look [it] up, but I don't know. And I assure you, I promise you, that I will look [it] up and I will go back to India at the first opportunity to work with them. That was my answer. I am still working with them. That is my answer to you. It's an ocean here because there are so many adivasis and Scheduled Tribes. But that is just a generic name for several disparate groups. Some we recognize as states, such as in the North-Eastern States, and the Tribal Hill Council referred to in the 6th Schedule [of the Indian Constitution].

SP: [Going back to the Millirrpum case] How did you find the solicitors to help you?

Upen: One student, Jim Spigelman asked them formally. They did the legwork. That a law firm would take up this case was itself a major victory for us. The legal culture was poised against everything we were doing. And the idea that students and teachers together could do a case together was unknown.

SP: How did the faculty respond?

Upen: Very badly. There were numerous snide remarks. This was not considered, and probably is not, let us face it, academic at all.

I studied at Berkeley with a man from Oxford, a legal historian of Ancient Rome called David Daube. Now the campus was burning, and I was marching, and he held in the Political Science Department a seminar which I audited, and the title of this seminar was "The Notion of Impossibility in Greek and Roman Law". And in the sixth or the seventh seminar I said: "David! You can't possibly be talking about ancient Greek and early Roman Law when the campus is burning over Vietnam. What does this have to do with this?" He looked at me and said: "I don't know much about Vietnam but someday you will understand about the importance of the notion of impossibility of law. How it started with Greek and Roman Law". His favourite example was how it started in Roman Law with Caligula's horse, which became a senator and he took an oath with his paw. So, I enjoyed it, but I then quit this seminar saying, "I can't stand it. I can't do my political action and my academics. I can't combine them beyond 
a point". And he said, "Fine. You are just auditing". We became very good friends. I met him in Berkeley just before he died. He was living in Berkeley and was ninety years old. He embraced me and said: "How nice to see you! Have you got five minutes? I will Xerox a manuscript I have just done!" I said: "David, I am not going to read it if it is on impossibility of law!" He said, "No! No! No! I have taken leave of Roman Law. I am now doing Canon Law!" [laughter].

I don't blame legal culture or would be lawyers or law faculties for having defined an academic role. As a University administrator [myself] I came across the stipulations of role, and I had to negotiate it in the Babri Masjid case in Ayodhya. My students at Delhi [University], student union president, my teacher's union president and members, my Karamchaari Union President, all went and helped in the demolition of the Masjid [Mosque]. As a Vice Chancellor, I always distinguished in my interventions. I did many public interventions and was considered an activist person always, but I had colleagues arguing against me for the public statement that I issued against the demolition. The demolishers had this strange slogan "Ek Dhakka Aur Do!" [Give one further push!]. I asked: "What was this dilapidated structure? You are attacking the Constitution of India. Ek Dhakka aur do to the Constitution." And I said that: "I speak this time as a Vice Chancellor, an Officer of the University." That is why the statement got noticed. Anyway, an academic statement of this kind is very rare. And my colleagues reacted by giving me the same definition of the academic role that I had encountered in Sydney. But I was in a different position in Delhi. Now I was at the receiving end and not the giving end. I replied to this, without mentioning colleagues by name, while I was still in office, I gave a Memorial Lecture for V.B. John, a great educationist of India. [This lecture] appears in [my book] Mambrino's Helmet and you can have a look at it. [In it] I said that universities have an academic role and a social role and that there are times that they should emphasize their social role and there are times that they should emphasize their academic role. There could be disagreement on what role should be emphasized but you must not forget that the bottom-line is this - that we all Indian citizens, bound by the Constitution and the Constitution means, to me - the Preamble; Rights or Part III, Directive Principles or Part IV; and Part IV A, Fundamental Duties. And among the Fundamental Duties is [the duty] to develop scientific temper, excellence in all walks of life ... and the spirit of social reform. As citizens we are bound to develop these. Now a teacher is a citizen. How does a teacher foster this? And that is where the roles have disrupted this distinction. The binary collapses because you are always having a social role [as a teacher], but you distinguish between a classroom role, and a role in research, and a role in public communication. You distinguish between inner limits and outer limits, whatever they are.

SP: As a teacher of jurisprudence what would you say to the teacher with a social conscience who does not like the Constitution? If you were in a system like Apartheid South Africa and the Constitution was bad, what would be your lodestar for social action and how would you justify a role for a public office?

Upen: It depends. Whether the Constitution gives us these liberties, duties, responsibilities or human rights, or whether certain core human rights standards precede even their enunciation. Were there no human rights before the UDHR? Now you have to go back to the whole history of natural law for that. Before positivism arose, we have nothing else but natural law. I distinguish between two trinities of Western thought. Two holy trinities. Hobbes, Locke and Rousseau, on the one side, and Freud, Marx and Nietzsche, on the other, and we are supposed to move in social theory with either this trinity or that trinity, that is all. Is there an Asian trinity, or an African trinity, or a Latin American trinity? We don't know. The mode of knowledge 
production [it seems] is one [singular]. That is why the importance of epistemic selfdetermination, Swaraj of ideas, for Mohandas. Or epistemic insubordination, in Mignolo's words, or to use Felix Gualtieri's phrase: "The fight against semiotic enslavement". Or what our friend Boaventura Santos calls 'epistemicide'. These are very precious notions. [Sometimes] ethics is all we have to fall back on. Rebellion. Steve Biko did not act according to the Constitution. They did not obey the legality of the Constitution because the Constitution preserved apartheid and therefore it was unjust. So, you have to go to the justice values of the political order and use every means that you have in practicing this semiotic freedom or in practicing resistance to enslavement or practicing resistance to epistemicide and so on.

In my young age now, I have realised the importance of the need to distinguish between two things. The idea of human rights and the law and jurisprudence of human rights. These are two distinct things. Although I have said a lot about these, I have not clearly distinguished them. The first one is a philosophical moral enterprise and the second one is a legal enterprise, intersecting with moral but not quite. Contingently intersecting.

SP: So, Upen, I have read a lot about what you have written about Eurocentrism, particularly of international law, and I was wondering whether you could say something about your understanding of the problem of Eurocentrism of international law and the strategies for struggling against it as a teacher?

Upen: You know all the answers! [laughs] As you have written a book on it. I don't know. I just play around. But playing around this is a very serious subject.

Eurocentrism is used in very many contexts, as you no doubt know. In early postcolonial literature it was used as 'Europe-centrism', not as Eurocentrism. It did not apply to all the West. It applied to Europe and certain countries within Europe which had colonised. So, if you look at Cabral, or if you look at Fanon or if you look at many other discourses, Nkrumah and others, you find constantly this old meaning of Europe-centrism, as distinct from Eurocentrism.

Then there is a different reference in international law which crystallised, now for some time, in this notion of 'civilised nations as standard'. Where the idea is that norm creation is a distinctly European/Western in character. That is [the narrative that] historically selfdetermination was 'invented' by Wilson, human rights were 'invented' by Eleanor Roosevelt. In other words, it is only civilised nations who can imagine ... The 'savages' can't. The 'noncivilised' can't ...

The core claim is that all norms and standards which control the States are essentially Eurocentric in origin and some would even go to the extent to say that they are Eurocentric in their development. If it is a historical claim, then it goes back to their revolutions. So, in international law, it is a claim to closure, basically. [A claim] that all norms develop and originate from Europe.

In my early writings, I take up Eurocentrism as the idea of the West, as a whole, the colonizing West. I was not very careful because my friend who was at Warwick, who is now at Florence, who worked on the Roma, always said he comes from the small non-colonizing part of Europe. So, when we refer to Europe, the question arises which Europe are we referring to? We are referring to Western Europe, which colonized. If you have read Packenham's book The Scramble for Africa there is a 'very nice' saying from King Leopold of Belgium that: "Africa is a very lovely piece of cake. I should have a slice too!" So, he takes over the Belgian Congo 
as a slice of cake. There were colonizing European nations and there were European nations which were non-colonizing. So, there is a question of history also.

In terms of my writing now, I [am attentive to] the difference between progressive Eurocentrism and regressive Eurocentrism. And the second thing is - is Eurocentrism a state of mind or a state of social organisation? They are two questions. Now, take the second question first, Eurocentrism as a state of mind is pretty universal. At least amongst the literate upper middle-class people. Frantz Fanon wrote a very long time ago a polemical book, that no one reads, called Black Skins, White Masks [1952]. Eurocentrism as a state of social consciousness of this class is a mentality that is supportive of Empires, that supports the centralization of power, even despotism. Eurocentrism as a state of mind is a very different thing from whether international law would apply to a specific territory and to a specific group of people, i.e. colonization. The interesting thing about this notion of Swaraj in ideas versus universal Eurocentrism of the social consciousness is a matter much to be explained and we don't really study it enough and therefore we cannot explain what is called neoliberalism. We can't even explain the idea that anything can be without contradictions. If you think that neoliberalism is a matter of no contradictions, with the historical contradiction between capital and labour being abolished, and no more contradictions remain, and that means that you have a theory of contradictions that is silent, when you talk of general Eurocentrism. Whereas, Ambedkar said in his famous speech ushering in the Constitution, that you have political equality but not economic inequality - this but that. So here there is a theory of institutional contradictions. There are [also] normative contradictions.

There are historical contradictions. And there is the original contradiction between capital and labour and between races, some 'born to rule' and some 'fit only to be ruled'. So, you need to think about neoliberalism as a contradictory unity, not as a surface without contradictions. If you mention authors, then you think with Negri and Spinoza and you need to launch your ethical insurgency. Even though these are European names. But when you are fighting a consciousness then you think with Fanon, you think with Nkrumah who defined neocolonialism. I will leave it there.

I have distinguished between regressive and progressive Eurocentrism over the last twelve years. As the regressive Eurocentrism is very clear, where you have colonies and colonizers. Now you have colonies without colonizers. So how do you confront the problem in any language of Eurocentrism is a question mark? But we can think of colonization, as you [Sundhya] have thought no doubt very well, in terms of control over territories, resources, environments and peoples - the de-subjectification of peoples. The erosion of self-rule or selfdetermination. That is the historical colonization of the last 250 years. Decolonization is a shorter process than the building of Empires. Unmaking takes a little less time than making. All that we think we know.

Progressive eurocentrism [on the other hand], and I have many friends who are progressively Eurocentric, is different. It says that some Eurocentrism is a good thing. But colonization is not a good thing. My favourite term for them is "A to $Z$ of progressive thinkers" - from Agamben to Zizek. I am very fond of Agamben and Zizek. There are many thinkers that lie in between. I am encompassing all the post-modern thinkers in that. Progressive Eurocentrism, I believe should be a subject-matter for a close examination. And the religious turn in progressive Eurocentrism is very important to me. This religious turn has happened with Badiou, the French thinker, who says that Christianity is a universal religion, and he has written a very good book on Saint Paul [Saint Paul: The Foundation of Universalism]. I am writing a book on Saint Paul 
from the Indian perspective. I hope I live long enough to finish that. I am very interested [in him] despite his misogynist overtones and other things. Paul has been excoriated by the feminists, I know, for good reason. But there is a Paul revival and Badiou, for example, said about Saint Paul that "He made Christianity Universal by a simple move, which is not to focus on crucifixion, because crucifixion was a normal method of punishing criminals. What was original in Saint Paul was his emphasis on resurrection and Christianity became a world religious system only with that discovery of redemption. Easter is more important than December [Christmas]". Crucifixion is a method of execution, but redemption is very new.

So progressive Eurocentrism is something I focus on now. And [the] human rights idea is a part of progressive Eurocentrism. Human rights are the progressive Eurocentric counterpoint to the fake universalism.

I don't know whether I have gone anywhere with this but that is briefly my [response].

SP: That is terrific. We have instructions from your Principal that we must stop [laughter]. So, thank you very much! 


\section{University Library}

\section{- M M N E R VA A gateway to Melbourne's research publications}

Minerva Access is the Institutional Repository of The University of Melbourne

Author/s:

Pahuja, S;Hasan Khan, A

Title:

The Southern Jurist as a Teacher of Laws: An Interview with Upendra Baxi

Date:

2018

Citation:

Pahuja, S. \& Hasan Khan, A. (2018). The Southern Jurist as a Teacher of Laws: An Interview with Upendra Baxi. Jindal Global Law Review, 9 (2), pp.351-373. https://doi.org/10.1007/ s41020-018-0081-3.

Persistent Link:

http://hdl.handle.net/11343/251326 